\title{
Faktor-faktor yang Berhubungan dengan Terjadinya Preeklampsia
}

\author{
Sudarman, ${ }^{1}$ Hermie M. M. Tendean, ${ }^{2}$ Freddy W. Wagey ${ }^{2}$
}

\author{
${ }^{1}$ Program Studi Pendidikan Dokter Fakultas Kedokteran Universitas Sam Ratulangi, Manado, \\ Sulawesi Utara, Indonesia \\ ${ }^{2}$ Bagian Ilmu Kebidanan dan Kandungan Fakultas Kedokteran Universitas Sam Ratulangi, \\ Manado, Sulawesi Utara, Indonesia \\ E-mail: armansudar@gmail.com
}

\begin{abstract}
Hypertension in pregnancy is still a major cause of maternal death. Preeclampsia affects about $2 \%$ to $8 \%$ of pregnancies worldwide. This study was aimed to determine the risk factors associated with the occurrence of preeclampsia. This was is a literature review study, using three databases, namely PubMed, ClinicalKey, and Google Scholar. The keywords used were risk factors OR faktor risiko AND preeclampsia OR preeklampsia. After being selected with inclusion and exclusion criteria, a critical appraisal was carried out and obtained 30 literatures consisting of 14 cross-sectional studies, 13 case control studies, and 3 cohort studies. The results found 30 literatures examined the relationship factors or characteristics of age, parity or gravida status, obesity, diabetes mellitus, chronic hypertension, history of kidney disease, history of preeclampsia, multiple pregnancies, family history of preeclampsia, duration between pregnancies, socioeconomic status (education levels and employment), and autoimmune diseases. In conclusion, the factors associated with the occurrence of preeclampsia are age at risk for pregnant women, nulliparity, primigravida, obesity, diabetes mellitus, chronic hypertension, history of kidney disease, history of preeclampsia, multiple pregnancies, family history of preeclampsia, distance between pregnancies, socioeconomic level, and autoimmune disease.
\end{abstract}

Keywords: risk factors, preeclampsia.

\begin{abstract}
Abstrak: Hipertensi dalam kehamilan masih menjadi penyebab kematian ibu yang cukup tinggi. Preeklampsia memengaruhi sekitar 2\% hingga 8\% kehamilan di seluruh dunia. Penelitian ini bertujuan untuk mengetahui faktor-faktor risiko yang berhubungan dengan terjadinya preeklampsia. Jenis penelitian ialah literature review, menggunakan tiga database yaitu PubMed, ClinicalKey, dan Google Scholar. Kata kunci yang digunakan yaitu risk factor OR faktor risiko $A N D$ preeclampsia OR preeklampsia. Setelah diseleksi dengan kriteria inklusi dan eksklusi dilakukan critical appraisal, didapatkan 30 literatur yang terdiri dari 14 cross-sectional study, 13 case control study, dan 3 cohort study. Hasil penelitian mendapatkan 30 literatur yang meneliti hubungan faktor atau karakteristik usia, paritas atau status gravida, obesitas, diabetes melitus, hipertensi kronik, riwayat penyakit ginjal, riwayat preeklampsia, kehamilan ganda, riwayat preeklampsia keluarga, jarak antar kehamilan, status sosial ekonomi (tingkat pendidikan dan pekerjaan), dan penyakit autoimun. Simpulan penelitian ini ialah faktor-faktor yang berhubungan dengan terjadinya preeklampsia yaitu usia ibu hamil berisiko, nuliparitas, primigravida, obesitas, diabetes melitus, hipertensi kronik, riwayat penyakit ginjal, riwayat preeklampsia, kehamilan ganda, riwayat preeklampsia keluarga, jarak antar kehamilan, tingkat sosioekonomi, dan penyakit autoimun.
\end{abstract}

Kata kunci: faktor risiko, preeklampsia

\section{PENDAHULUAN}

Menurut data pada tahun 2010, dilaporkan pada negara dengan pendapatan mene- ngah ke bawah memiliki rasio kematian ibu sebanyak 240 per 100.000 kelahiran hidup dibandingkan dengan 16 per 100.000 kela- 
hiran hidup pada negara berpendapatan tinggi. ${ }^{1}$ Kematian yang terjadi selama kehamilan sebesar $24 \%$, saat melahirkan atau seminggu setelah melahirkan sebesar 34\%, 742 hari setelah melahirkan sebesar $19 \%$, dan 43-365 hari setelah melahirkan sebesar $24 \%{ }^{2}$

Berdasarkan Riskesdas 2018, jenis gangguan atau komplikasi dalam kehamilan diantaranya muntah/diare terus menerus $(20,0 \%)$, demam tinggi $(2,4 \%)$, hipertensi $(3,3 \%)$, janin kurang bergerak $(0,9 \%)$, perdarahan pada jalan lahir $(2,6 \%)$, keluar air ketuban $(2,7 \%)$, kaki bengkak disertai kejang $(2,7 \%)$, batuk lama (2,3\%), nyeri dada/ jantung berdebar $(1,6 \%)$, dan lainnya $(7,2 \%){ }^{3}$ Pada tahun 2013 , dilaporkan penyebab kematian ibu diantaranya perdarahan $(30,3 \%)$, hipertensi $(27,1 \%)$, infeksi $(7,3 \%)$, dan lain-lain $(40,8 \%) .{ }^{4}$ Data Profil Kesehatan Indonesia tahun 2019, mencatat kematian akibat Hipertensi Dalam Kehamilan (HDK) sebanyak 1.066 kasus. $^{5}$

Hipertensi dalam kehamilan diklasifikasikan menjadi hipertensi kronik, preeklampsia, hipertensi kronik superimposed preeklampsia, dan hipertensi gestasional. Hipertensi kronik menjadi penyulit sekitar $3 \%$ hingga $5 \%$ pada wanita hamil di Amerika Serikat. Preeklampsia sendiri memengaruhi sekitar $2 \%$ hingga $8 \%$ kehamilan di seluruh dunia. ${ }^{6}$

American College of Obstetricians and Gynecologists (ACOG) membagi faktor risiko preeklampsia menjadi tiga tingkatan yaitu risiko rendah, sedang dan tinggi. Persalinan dengan bayi cukup bulan sebelumnya termasuk risiko rendah. nuliparitas, Indeks Massa Tubuh (IMT) $>30 \mathrm{~kg} / \mathrm{m}^{2}$, riwayat keluarga dengan preeklampsia, karakteristik sosiodemografi, usia $>35$ tahun, faktor riwayat pribadi (seperti berat bayi lahir rendah sebelumnya dan jarak kehamilan sebelumnya lebih dari 10 tahun) termasuk dalam faktor risiko sedang. Uuntuk faktor risiko tinggi diantaranya riwayat preeklampsia sebelumnya, kehamilan ganda, hipertensi kronik, diabetes tipe 1 atau 2, penyakit ginjal, dan gangguan autoimun. ${ }^{7}$ Penyakit jantung juga menjadi salah satu faktor risiko preeklampsia. $^{8}$
Penelitian yang dilakukan di RSUP Dr. Mohammad Hoesin Palembang menyebutkan faktor risiko preeklampsia yaitu usia maternal $\geq 35$ tahun, IMT $\geq 23,0 \mathrm{~kg} / \mathrm{m}^{2}$, dan riwayat hipertensi dalam kehamilan. Faktor risiko yang berhubungan tidak bermakna dengan kejadian preeklampsia diantaranya pekerjaan tetap, jarak kehamilan ekstrim, dan riwayat penyakit maternal. ${ }^{9}$ Obesitas memiliki risiko tinggi mengalami preeklampsia sebesar 25 kali dibandingkan yang tidak obesitas. Pasien dengan resistensi insulin memiliki risiko tinggi 4 kali untuk menderita preeklampsia dibandingkan yang tidak mengalami resistensi insulin. ${ }^{10}$

Data secara global dan nasional masih menunjukkan angka yang tinggi terkait kejadian preeklampsia. Banyak faktor yang kemungkinan berperan dalam terjadinya preeklampsia; hal ini yang menjadi latar belakang sehingga penulis tertarik untuk meneliti mengenai faktor-faktor yang berhubungan dengan terjadinya preeklampsia.

\section{METODE PENELITIAN}

Penelitian ini berbentuk literature review. Pencarian literatur melalui publikasi di tiga database dengan menggunakan kata kunci ("risk factor" OR "faktor risiko") AND (preeclampsia OR preeklampsia). Dari hasil pencarian tersebut peneliti mendapatkan artikel sebanyak 208 menggunakan PubMed, 3.565 menggunakan ClinicalKey, dan 17.200 menggunakan Google Scholar $(\mathrm{n}=20.973)$ yang sesuai dengan kata kunci tersebut. Dari hasil pencarian yang didapat selanjutnya dilakukan skrining judul yang sesuai dengan topik literature review diperoleh 288 artikel $(\mathrm{n}=288)$. Selanjutnya dilakukan skrining judul yang tersedia abstrak dan full text terhadap 288 artikel dan diperoleh 78 artikel $(n=78)$. Skrining literatur sesuai kriteria inklusi dan eksklusi terhadap 78 artikel, memperoleh 30 artikel yang memenuhi kriteria $(n=30)$.

\section{HASIL PENELITIAN}

Dari 30 literatur yang telah memenuhi kriteria inklusi dan eksklusi, 14 diantaranya 
berupa cross-sectional study, 13 lainnya berupa case control study, dan 3 diantaranya berupa cohort study. Terdapat 20 literatur yang melakukan penelitian di Indonesia dan 10 literatur di luar Indonesia. Dari 30 literatur yang ada, 16 menggunakan bahasa Indonesia dan 14 lainnya menggunakan bahasa Inggris. Tabel 1 memperlihatkan karakteristik dari 30 jurnal yang digunakan dalam penelitian ini.

Tabel 1. Karakteristik jurnal berdasarkan penulis, tahun, judul, tempat, metode, dan ringkasan hasil penelitian

\begin{tabular}{|c|c|c|c|}
\hline Penulis Jurnal (Tahun) dan Judul & Tempat Penelitian & $\begin{array}{c}\text { Jenis } \\
\text { Penelitian }\end{array}$ & Hasil Penelitian \\
\hline $\begin{array}{l}\text { Harumi AM dan Armadani DK } \\
\text { (2019), "Hubungan Primigravida } \\
\text { Dengan Kejadian Preeklampsia pada } \\
\text { Ibu Hamil di Puskesmas Jagir }\end{array}$ & $\begin{array}{l}\text { Puskesmas } \\
\text { Surabaya. }\end{array}$ & $\begin{array}{l}\text { Cross } \\
\text { sectional }\end{array}$ & $\begin{array}{l}\text { Dari uji statistik didapatkan hubungan } \\
\text { antara status gravida ( } p \text {-value }=0,027) \\
\text { dengan preeklampsia. }{ }^{11}\end{array}$ \\
\hline
\end{tabular}

di Puskesmas Jagir Surabaya".11

Aulia D, Rodiani, dan Graharti R (2019), "Hubungan Diabetes Melitus dengan Kejadian Preeklampsia di RSUD DR. H. Abdul Moeloek Provinsi Lampung Periode 1 Januari 30 Juni $2018 " .12$

Rahmawati I, Anies, Adi MS, dan Hadi C (2020), "Maternal age $\geq 35$ years, Nulliparity, High Blood $\mathrm{COHb}$ Levels, and Low Serum Nitric Oxide Levels Increased Risk of Preeclampsia". ${ }^{13}$

Sadidi M, Bustan MN, Gobel FA, dan Sartika (2019), “Analisis Faktor Risiko Kejadian Preeklampsia Di RSKD Ibu Dan Anak Siti Fatimah Kota Makassar". ${ }^{14}$

Mukhoirotin, Fatmawati DA, dan Shofiana N (2018), "Relationship Between Age and Gravidity with Preeclampsia Incident among Pregnant Women at Puskesmas Cukir Jombang". ${ }^{15}$

Nisa R, Kartasurya MI, dan Fatimah S (2018), “Asupan Vitamin D, Obesitas dan Paparan Asap Rokok sebagai Faktor Risiko Preeklampsia". ${ }^{16}$

Bardja S (2020), "Faktor Risiko Kejadian Preeklampsia Berat/ Eklampsia pada Ibu Hamil". ${ }^{17}$

Fajarsari D dan Prabandari F (2018), "Pengaruh Umur Dan Interval Persalinan Terhadap Kejadian Preeklampsia Di Kabupaten Banyumas". ${ }^{18}$

Wulandari S (2016), "Hubungan Antara Jarak Kehamilan Dan Status Gizi Dengan Kejadian Preeklampsia Pada Ibu Hamil Di RS Aura Syifa
RSUD

Arjawinangun,

Cirebon.

RSUP DR. H. Abdul Moeloek Provinsi Lampung.

Puskesmas Nalumsari,

Puskesmas Mayong

2, dan Puskesmas

Kalinyamatan di

Kabupaten Jepara.

RSKD Ibu dan Anak Siti Fatimah Kota

Makassar.

Puskesmas

Cukir Case control Jombang.

Puskesmas

Kabupaten

Indramayu.

Kabupaten

Banyumas.

RS Aura Syifa Cross Kabupaten Kediri. sectional
Case control Didapatkan $p$-value $=0,018$ untuk diabetes melitus. ${ }^{12}$

Case control Diperoleh untuk faktor usia ( $p$-value $=0,011)$ dan paritas $(p$-value $=0,023){ }^{13}$

Case control Diperoleh usia (p-value $=0,025)$, tingkat pendidikan $(p$-value $=0,039)$, dan paritas $(p$-value $=0,005){ }^{14}$

Case control Hasil penelitian didapatkan faktor risiko usia $(p$-value $=0,001)$, riwayat preeklampsia sebelumnya $(p$-value $=$ $0,001)$, riwayat preeklampsia dalam keluarga $(p$-value $=0,001)$, obesitas $(p$-value $=0,001) .{ }^{16}$

Case control Hasil penelitian menunjukkan ada hubungan usia $(p=0,000)$ pendidikan $(p=0,000)$, paritas $(p=$ $0,003)$, obesitas $(p=0,000)$, riwayat preeklampsia $(p=0,000)$, riwayat penyakit keluarga $(p=0,000)$, dan jumlah janin $(p=0,0061) \cdot{ }^{17}$

Case control Faktor risiko usia ( $p$-value $=0,009)$ dan interval persalinan ( $p$-value $=$ $0,009)$ memiliki pengaruh terhadap terjadinya preeklampsia. ${ }^{18}$

Terdapat hubungan antara jarak antar kehamilan $\quad(p$-value $=0,006) \quad$ dan obesitas $(p$-value $=0,030) \quad$ dengan preeklampsia. ${ }^{19}$ 
Kabupaten Kediri Tahun 2015". ${ }^{19}$

Laila EF (2019), "Hubungan Usia, Paritas, Riwayat Hipertensi, Dan Frekuensi Pemeriksaan ANC Terhadap Kejadian Preeklampsia Pada Ibu Hamil". ${ }^{20}$

Haryani AP, Maroef M, dan Adilla SN (2015), "Hubungan Usia Ibu Hamil Berisiko Dengan Kejadian Preeklampsia/Eklampsia Di RSU Haji Surabaya Periode 1 Januari 2013-31 Desember 2013". ${ }^{21}$

Arwan B dan Sriyanti R (2020), "Relationship between Gravida Status, Age, BMI (Body Mass Index) and Preeclampsia". ${ }^{22}$

Hasliani A (2018), "Hubungan Riwayat Hipertensi Dengan Kejadian Preeklampsia Di RSUD Pangkep". ${ }^{23}$

Opitasari C dan Andayasari L (2014), "Parity, Education Level, and Risk for (pre-) eclampsia in Selected Hospitals in Jakarta". ${ }^{24}$

Kurniasari D dan Arifandini F (2015), "Hubungan Usia, Paritas Dan Diabetes Melitus Pada Kehamilan Dengan Kejadian Preeklampsia Pada Ibu Hamil Di Wilayah Kerja Puskesmas Rumbia Kabupaten Lampung Tengah Tahun 2014". 25

Marniati, Rahmi N, dan Djokosujono K (2016), "Analisis Hubungan Usia, Status Gravida dan Usia Kehamilan dengan Preeklampsia pada Ibu Hamil di Rumah Sakit Umum dr. Zainoel Abidin Provinsi Aceh Tahun 2015" ${ }^{26}$

Wahyuni R, Azhari, dan Syukur NA (2019), "Hubungan Obesitas Dengan Preeklampsia Pada Ibu Hamil Trimester II Dan III". ${ }^{27}$

Denantika O, Serudji J, dan Revilla G (2015), "Hubungan Status Gravida dan Usia Ibu terhadap Kejadian Preeklampsia di RSUP Dr. M. Djamil Padang Tahun 2012-2013". ${ }^{28}$

Yanuarini TA, Suwoyo, dan Julianawati T (2020), "Hubungan Status Gravida dengan Kejadian Preeklampsia". ${ }^{29}$

Andriyani R (2012), "Faktor Risiko Kejadian Preeklampsia di RSUD Arifin Achmad". 30

Luealon P dan Phupong V (2010), "Risk Factors of Preeclampsia in Thai Women". ${ }^{31}$
Ruang Paus RSUD Cross

Palabuhan Ratu sectional

Kabupaten

Sukabumi.
RSU Haji Surabaya. Cross sectional

Department of Cross Gynecology Dr. M. Djamil Padang.

RSUD Pangkep.

Cross sectional

RS yang telah Cross dipilih di Jakarta. sectional

Puskesmas Rumbia Cross Kabupaten sectional Lampung Tengah.

Rumah Sakit Umum dr. Zainoel Abidin

Cross Provinsi Aceh. Obstetrics and sectional

Diperoleh faktor usia ( $p$ value $=0,001), \quad$ paritas ( $p$-value $=0,015)$, dan riwayat hipertensi kronik $(p$-value $=0,01){ }^{20}$

Dari analisis uji Chi-Square didapatkan nilai $p=0,000$ yang berarti terdapat hubungan. ${ }^{21}$

Terdapat hubungan untuk faktor usia ( $p$-value $=0,001)$,

status gravida $(p$-value $=0,001), \quad$ dan obesitas $(p$-value $=0,001) .{ }^{22}$

Hasil analisis bivariat didapatkan nilai $p=0,001$ untuk faktor riwayat hipertensi dengan kejadian preeklampsia. ${ }^{23}$

Dari uji bivariat didapatkan hasil untuk faktor usia ( $p$-value $=0,004)$, tingkat pendidikan ( $p$-value $=0,005)$, pekerjaan $(p$-value $=0,018)$, paritas $(p$-value $=0,000)$, dan riwayat hipertensi kronik $p$-value $=0,000) .{ }^{24}$

Hasil uji Chi-square didapatkan usia ibu bersiko terhadap preeklampsia dengan nilai $p$-value $=0,000$, paritas ibu hamil dengan preeklampsia $p$ value $=0,008$, dan diabetes melitus dengan preeklampsia $p$-value $=$ $0,000 .^{25}$

Hasil variabel usia ( $p$-value $=0,001)$, variabel status gravida ( $p$-value $=$ $0,003)$, dan usia kehamilan ( $p$-value $=$ $0,039){ }^{26}$

\begin{tabular}{|c|c|c|}
\hline $\begin{array}{l}\text { RSUD } \\
\text { Wahab }\end{array}$ & $\begin{array}{r}\text { Abdul } \\
\text { Sjahranie }\end{array}$ & $\begin{array}{l}\text { Cross } \\
\text { sectional }\end{array}$ \\
\hline \multicolumn{3}{|c|}{ Samarinda. } \\
\hline $\begin{array}{l}\text { RSUP } \\
\text { Djamil F }\end{array}$ & $\begin{array}{ll}\text { Dr. } & \text { M. } \\
\text { dang. }\end{array}$ & $\begin{array}{l}\text { Cross } \\
\text { sectional }\end{array}$ \\
\hline
\end{tabular}

Diperoleh $p$-value $=0,006$ yang berarti terdapat hubungan antara obesitas dengan preeklampsia pada ibu hamil trimester II dan III. ${ }^{27}$

Dari uji statistik untuk faktor usia ( $p$ value $=0,001)$ dan status gravida ( $p$ value $=0,036){ }^{28}$

Puskesmas Ngasem, $C$ ase Hasil uji Chi-square didapatkan $p$ Kabupaten Kediri. control value $=0,038 .^{29}$

RSUD Arifin Achmad Provinsi Riau.

King Chulalongkorn Memorial Hospital, Bangkok, Thailand.
Case control Faktor yang berhubungan dengan terjadinya preeklampsia yaitu usia $(p$-value $=0,028)$, paritas $(p$-value 
Tangren JS dkk (2018), "Risk of Preeclampsia and Pregnancy Complications in Women With a History of Acute Kidney Injury", 32

Laine K, Murzakanova G, Sole KB, Pay AD, Heradstveit S, dan Räisänen S (2019), "Prevalence and risk of preeclampsia and gestational hypertension in twin pregnancies: A population-based register study". ${ }^{33}$

Verma MK, Kapoor P, Yadav R, dan Manohar RK (2017), "Risk Factor Assessment for Pre-eclampsia: A Case Control Study".34

Quan LM, Xu QL, Zhang GQ, Wu LL dan $\mathrm{Xu} \mathrm{H}$ (2017), "An analysis of the risk factors of preeclampsia and prediction based on combined biochemical indexes". 35

Shao Y, dkk (2017), "Pre-pregnancy $B M I$, gestational weight gain and risk of preeclampsia: a birth cohort study in Lanzhou, China". ${ }^{36}$

Hussein YA, Ali RK, dan Alezzi JI (2018), "Preeclampsia: Maternal Risk Factors \& Perinatal Outcomes". ${ }^{37}$

Das S dkk (2019), "Incidence and Risk Factors of Pre-Eclampsia in the Paropakar Maternity and Women's Hospital, Nepal: A Retrospective Study".38

Harutyunyan A, Armenian $\mathrm{H}$ dan Petrosyan V (2013), "Interbirth Interval And History of Previous Preeclampsia: A Case-Control Study Among Multiparous Women". ${ }^{39}$

Rajaei E dkk (2019), "The effect of lupus disease on the pregnant women and embryos: a retrospective study from 2010 to 2014". ${ }^{40}$
Massachusetts General Hospital.

Medical Birth
Registry of Norway.

Cohort

Mahila chikitsalaya, Jaipur, India.

Jinhua People's Hospital, Jinhua, China

Lanzhou, China.

Cohort

Maternity and Cros Pediatric Hospital sectional (ZMPH) in AlMuqdadia District in Diyala provincel Iraq.

Paropakar Maternity and Women's Hospital,

Kathmandu, Nepal.

Rumah Sakit di Yerevan, Armenia.

Golestan Hospital, Jundishapur University of Medical Sciences in Ahwaz, Iran.

Cross
$=0,001)$, kehamilan kembar ( $p$-value $=0,02)$, obesitas $(p$-value $=0,004)$, riwayat hipertensi kronik ( $p$-value $=$ $0,002)$, dan riwayat preeklampsia ( $p$ value $=0,009) .{ }^{31}$

Cohort Wanita dengan r-AKI mengalami peningkatan tingkat preeklampsia dibandingkan dengan wanita tanpa $\mathrm{r}$ AKI sebelumnya $p$-value $<0,001) .{ }^{32}$

Terdapat hubungan antara kehamilan kembar dengan kejadian preeklampsia $(p=0,001) .{ }^{33}$

Case control

Analisis bivariat menemukan bahwa preeklampsia signifikan terkait dengan usia $(p$-value $=0,001)$, paritas $(p$-value $=0,001)$, obesitas $(p$-value $=$ $0,001)$, riwayat preeklampsia ( $p$-value $=0,001)$, dan riwayat preeklampsia keluarga $(p$-value $=0,001)$, namun tidak pada jarak antar kehamilan ( $p$ value $=0,476) .{ }^{34}$

Terdapat hubungan antara Obesitas $(p$-value $=0,026)$, riwayat hipertensi kronik $\quad(p$-value $=0,004)$, dan diabetes melitus $(p$-value $=0,039)$ dengan preeklampsia. ${ }^{35}$

Diperoleh untuk faktor Usia ( $p$-value $=0,001)$, tingkat pendidikan ( $p$-value $=0,0001)$, pekerjaan ( $p$-value $=$ $0,0012)$, paritas $(p$-value $=0,0035)$, kehamilan kembar ( $p$-value $=$ $0,0001)$, dan obesitas ( $p$-value $=$ $0,0001) \cdot{ }^{36}$

Terdapat hubungan antara usia ( $p$ value $=0,04)$, status gravida ( $p$-value $=0,01)$, dan obesitas ( $p$-value = $0,001)$ dengan kejadian preeklampsia. $^{37}$

Dari uji statistik didapatkan untuk usia $(p$-value $=0,005)$, paritas $(p$ value $=0,005)$, kehamilan kembar $(p$-value $=0,000)$, dan riwayat hipertensi kronik ( $p$-value $=0,000){ }^{38}$

Case control Terdapat hubungan antara jarak antar kehamilan $(p$-value $=0,0005)$, dan riwayat preeklampsia ( $p$-value $=$ $0,0005)$ dengan kejadian preeklampsia. $^{39}$

Hasil penelitian menunjukkan bahwa adanya sindrom antifosfolipid pada ibu hamil dapat menyebabkan komplikasi seperti nefritis, artritis, dan preeklampsia pada ibu ( $p$-value $0,003) \cdot{ }^{40}$

\section{BAHASAN}

Kajian penelitian ini meliputi 12 faktor risiko preeklampsia, yaitu usia, paritas, obesitas, diabetes melitus, hipertensi kronik, riwayat penyakit ginjal, riwayat ekklampsia, kehamilan ganda, riwayat preeklampsia 
keluarga, jarak antar kehamilan, tingkat sosioekonomi, dan penyakit autoimun.

\section{Usia}

Dari literatur yang telah dilakukan review, didapatkan 20 literatur yang meneliti hubungan usia ibu hamil dengan kejadian preeklampsia. Dari kedua puluh jurnal tersebut didapatkan nilai $\mathrm{p}<0,05$ yang berarti terdapat hubungan antara usia ibu hamil berisiko ( $<20$ tahun atau $>30$ tahun) dengan kejadian preeklampsia.

Usia hamil yang tidak berisiko yaitu antara 20-35 tahun. Rentang usia tersebut merupakan usia reproduktif yang aman untuk hamil karena komplikasi kehamilan yang sedikit sedangkan usia ibu hamil kurang dari 20 tahun atau lebih dari 35 tahun merupakan rentang usia yang berisiko karena kejadian komplikasi meningkat pada usia tersebut. ${ }^{28}$

Perkembangan pesat baik secara fisik, mental, dan intelektual terjadi pada saat masa remaja. Kehamilan pada usia muda atau remaja memiliki dampak pada kesehatan remaja dan bayinya serta dampak sosial dan ekonomi. Kehamilan pada usia remaja memiliki risiko tinggi untuk mengalami komplikasi kehamilan dibandingkan usia kehamilan 20-39 tahun. ${ }^{41}$ Seperti disebutkan sebelumnya, pada usia <20 tahun masih terjadi pertumbuhan seperti ukuran uterus yang belum mencapai ukuran normal untuk kehamilan. Hal ini dapat menyebabkan risiko preeklampsia meningkat. ${ }^{28}$

Wanita dengan usia $>35$ tahun kemungkinan telah terjadi proses degeneratif yang memengaruhi pembuluh darah perifer sehingga terjadi perubahan fungsional dan struktural yang berperan pada perubahan tekanan darah, sehingga lebih rentan mengalami preeklampsia. ${ }^{28}$ Wanita usia $>35$ tahun lebih rentan untuk mengalami preeklampsia dibandingkan wanita pada usia 20-35 tahun. ${ }^{42}$ Menurut Lamminpaa et $\mathrm{al},{ }^{43} \mathrm{ibu}$ hamil dengan usia di atas 35 tahun memiliki kemungkinan 1,5 kali menderita preeklampsia dibandingkan ibu hamil dengan usia kurang dari 35 tahun.

\section{Paritas.}

Literatur yang meneliti hubungan paritas dengan kejadian preeklampsia, yaitu Rahmawati et $\mathrm{al}^{13}(\mathrm{p}=0,023)$, Sadidi et $\mathrm{al}^{14}$ $(\mathrm{p}=0,005), \operatorname{Bardja}^{17}(\mathrm{p}=0,003)$, Laila ${ }^{20}(\mathrm{p}=$ $0,015)$, Opitasari dan Andayasari ${ }^{24}(\mathrm{p}=$ $0,000)$, Kurniasari dan Arifandini ${ }^{25}(\mathrm{p}=$ $0,008)$, Luealon dan Phupong ${ }^{31}(\mathrm{p}=0,001)$, Verma et $\mathrm{al}^{34}(\mathrm{p}=0,001)$, Shao et $\mathrm{al}^{36}$ $(\mathrm{p}=0,0035)$, dan Das et $\mathrm{al}^{38}(\mathrm{p}=0,005)$. Dari kesepuluh literatur tersebut didapatkan nilai $\mathrm{p}<0,05$ yang berarti terdapat hubungan antara paritas dengan kejadian preeklampsia.

Selain itu, didapatkan juga literatur yang meneliti hubungan status gravida dengan kejadian preeklampsia. Terdapat delapan literatur yang meneliti hubungan tersebut diantaranya Harumi dan Armadani $^{11}(\mathrm{p}=0,027)$, Mukhoirotin et $\mathrm{al}^{15}(\mathrm{p}=$ $0,002)$, Arwan dan Sriyanti ${ }^{22}(\mathrm{p}=0,001)$, Marniati et $\mathrm{al}^{26}(\mathrm{p}=0,003)$, Denantika et $\mathrm{al}^{28}$ $(\mathrm{p}=0,036)$, Yanuarini et $\mathrm{al}^{29} \quad(\mathrm{p}=0,038)$, Andriyani $^{30}(\mathrm{p}=0,001)$, dan Hussein et $\mathrm{al}^{37}$ $(\mathrm{p}=0,01)$. Dari kedelapan literatur tersebut didapatkan nilai $\mathrm{p}<0,05$ yang berarti terdapat hubungan antara status gravida dan kejadian preeklampsia.

Sebuah teori menyebutkan kejadian preeklampsia pada kehamilan pertama berhubungan dengan peran faktor imunologi. Pada kehamilan pertama terjadi pembentukan pemblokiran antibodi terhadap situs antigenik plasenta yang mungkin terganggu, sehingga meningkatkan risiko preeklampsia. ${ }^{42}$ Berdasarkan Bdolah et al, ${ }^{44}$ wanita dengan nuliparitas memiliki tingkat sirkulasi sFlt1 dan rasio sFlt1/PlGF yang lebih tinggi dibandingkan wanita dengan multiparitas yang menunjukkan adanya hubungan ketidakseimbangan faktor angiogenik.

\section{Obesitas.}

Dari tiga puluh literatur yang telah dikumpulkan, didapatkan sepuluh literatur yang meneliti hubungan obesitas dengan kejadian preeklampsia. Sepuluh literatur tersebut diantaranya Nisa et $\mathrm{al}^{16}(\mathrm{p}=0,001)$, $\operatorname{Bardja}^{17}(\mathrm{p}=0,000)$, Wulandari ${ }^{19}(\mathrm{p}=0,030)$, Arwan dan Sriyanti ${ }^{22}$ (p 0,001), Wahyuni et $\mathrm{al}^{27}(\mathrm{p}=0,006)$, Luealon dan Phupong ${ }^{31}$ 
$(p=0,004)$, Verma et $\mathrm{al}^{34}(\mathrm{p}=0,001)$, Quan et $\mathrm{al}^{35}(\mathrm{p}=0,026)$, Shao et $\mathrm{al}^{36}(\mathrm{p}=0,0001)$, dan Hussein et $\mathrm{al}^{37}(\mathrm{p}=0,001)$. Dari kesepuluh literatur tersebut didapatkan nilai $\mathrm{p}<0,05$ yang berarti terdapat hubungan antara obesitas dengan kejadian preeklampsia.

Obesitas meningkatkan risiko preeklampsia. Dengan demikian, risiko preeklampsia berat dan ringan serta preeklampsia yang terjadi pada awal dan akhir kehamilan lebih besar pada wanita obesitas dan kelebihan berat badan. Sebuah teori menyebutkan bahwa antioksidan memiliki peran untuk menghambat terjadinya preeklampsia. Wanita yang obesitas memiliki konsentrasi antioksidan dalam darah yang lebih rendah. ${ }^{45}$ Berdasarkan penelitian Sibai et al, ${ }^{46}$ semakin tinggi berat kehamilan maka semakin tinggi risiko mengalami preeklampsia.

Obesitas dapat memengaruhi fungsi dan perfusi plasenta, melalui beberapa perubahan metabolik yang berhubungan dengan obesitas seperti hiperlipidemia, hiperinsulinemia, atau hyperleptinemia. Penanda metabolik ini diketahui meningkat pada plasma wanita hamil yang mengalami obesitas dan bahkan lebih tinggi pada wanita dengan preeklampsia. Selain itu, telah dilaporkan bahwa kadar kolesterol serum total pada trimester pertama dan kedua kehamilan dapat memprediksi terjadinya preeklampsia. Perubahan profil lipid yang terdiri dari peningkatan low-density lipoprotein (LDL), rendahnya kadar highdensity lipoprotein (HDL), dan peningkatan kadar trigliserida pada wanita dengan preeklampsia. Telah dilaporkan bahwa LDL mengurangi migrasi sitotrofoblas ekstravili dan meningkatkan apoptosis trofoblas. Juga, tingginya kadar trigliserida dan asam lemak bebas, yang meningkat pada obesitas, meningkatkan risiko preeklampsia dan meningkat pada preeklampsia. ${ }^{47}$

\section{Diabetes melitus}

Setelah melakukan pencarian literatur, didapatkan tiga literatur yang meneliti hubungan antara diabetes melitus dengan kejadian preeklampsia, yaitu Aulia et al ${ }^{12}$ $(\mathrm{p}=0,018)$, Kurniasari dan Arifandini ${ }^{25}(\mathrm{p}=$ $0,000)$, dan Quan et $\mathrm{al}^{35}(\mathrm{p}=0,039)$. Berda- sarkan ketiga literatur tersebut didapatkan nilai $\mathrm{p}<0,05$ yang berarti terdapat hubungan antara diabetes melitus dengan kejadian preeklampsia.

Kejadian preeklampsia meningkat pada wanita dengan diabetes. ${ }^{42}$ Berdasarkan penelitian Yanit et al, ${ }^{48}$ preeklampsia lebih mungkin terjadi pada wanita dengan diabetes sebesar tiga sampai empat kali. Pada wanita diabetes dengan hipertensi kronik memiliki kemungkinan 12 kali menderita preeklampsia.

Peningkatan kadar glukosa memiliki efek yang sama pada perkembangan preeklampsia. Glukosa yang berlebih selama kehamilan menghambat fungsi sel sitotrofoblas (CTB) dengan menginduksi pensinyalan jalur stres (P38 MAPK dan PPAR $\gamma$ ) diikuti dengan penghambatan MMP-9 yang menyebabkan migrasi CTB dan komplikasi invasi, stres oksidatif yang menyebabkan hipoksia plasenta, dan peningkatan IL6 yang menyebabkan ketidakseimbangan angiogenik. Semua perubahan ini tampaknya berkontribusi pada jalur umum akhir yang mengarah ke plasentasi abnormal, sehingga berkembangnya preeklampsia. $^{49}$

\section{Hipertensi kronik}

Literatur yang meneliti faktor risiko hipertensi kronik, yaitu Laila ${ }^{20}(\mathrm{p}=0,01)$, Hasliani $^{23}(\mathrm{p}=0,001)$, Opitasari dan Andaya$\operatorname{sari}^{24}(\mathrm{p}=0,000)$, Luealon dan Phupong ${ }^{31}$ $(\mathrm{p}=0,002)$, Quan et $\mathrm{al}^{35}(\mathrm{p}=0,004)$, dan Das et $\mathrm{al}^{38} \quad(\mathrm{p}=0,000)$. Dari enam literatur tersebut, diperoleh nilai $\mathrm{p}<0,05$ yang berarti terdapat hubungan antara hipertensi kronik dengan kejadian preeklampsia.

Pada wanita dengan hipertensi kronik terjadi penurunan tekanan darah pada awal kehamilan dan meningkat kembali pada trimester ketiga. ${ }^{42}$ Komplikasi paling sering dalam kehamilan pada wanita dengan hipertensi kronik adalah preeklampsia. Pada sebuah penelitian terhadap 763 wanita dengan hipertensi kronik dilaporkan 25\% mengalami superimposed preeklampsia, angka tersebut meningkat pada wanita yang telah mengalami hipertensi $>4$ tahun. ${ }^{50}$

Salah satu faktor predisposisi pre- 
eklampsia berat ialah riwayat hipertensi, penyakit hipertensi vaskular sebelumnya, atau hipertensi esensial. Hipertensi yang diderita sebelum kehamilan mengakibatkan gangguan/kerusakan pada organ-organ penting tubuh. Kehamilan itu sendiri membuat berat badan naik sehingga dapat mengakibatkan gangguan/kerusakan yang lebih parah, yang ditunjukkan dengan edema dan proteinuria. ${ }^{51}$

\section{Riwayat penyakit ginjal}

Setelah melakukan pencarian literatur, didapatkan satu literatur yang meneliti hubungan riwayat penyakit ginjal dengan kejadian preeklampsia. Berdasarkan hasil penelitian Tangren et $\mathrm{al}^{32}$ didapatkan $\mathrm{p}=$ 0,001 yang berarti terdapat hubungan antara riwayat penyakit ginjal dengan kejadian preeklampsia.

Semua wanita dengan penyakit ginjal kronik memiliki insiden terjadinya preeklampsia tinggi. ${ }^{42}$ Hipertensi dan penyakit ginjal yang sudah ada sebelumnya meningkatkan risiko hasil kehamilan yang merugikan, terutama peningkatan risiko preeklampsia. ${ }^{52}$ Menurut Tangren et al, ${ }^{32} \mathrm{ibu}$ hamil dengan riwayat gangguan ginjal akut memiliki risiko mengalami preeklampsia 2,9 kali lebih besar dibandingkan ibu hamil yang tidak memiliki riwayat gangguan ginjal akut.

Wanita dengan akut kidney injury (AKI) yang pulih secara klinis, terutama mereka dengan AKI berat, memiliki sisa penyakit ginjal subklinis dan massa nefron rendah sebelum memasuki kehamilan. Jumlah nefron dapat berkurang hingga 50\% sebelum kreatinin serum naik di atas kisaran normal. Jumlah nefron rendah dan pengganti untuk massa ginjal rendah telah dikaitkan dengan konsekuensi kesehatan jangka panjang yang merugikan, termasuk hipertensi dan gangguan ginjal kronik. Jumlah nefron yang rendah juga tampaknya menjadi faktor risiko komplikasi kehamilan. Kehamilan dikaitkan dengan perubahan besar dalam aliran plasma ginjal yang menyebabkan peningkatan GFR sebesar $50 \%$ saat midgestasi. Penurunan hiper- filtrasi kehamilan telah diidentifikasi sebagai faktor risiko preeklampsia, kelahiran prematur, dan berat lahir rendah. ${ }^{32}$

\section{Riwayat preeklampsia}

Dari tiga puluh literatur yang telah dikumpulkan, terdapat enam penelitian yang meneliti hubungan antara riwayat preeklampsia dengan preeklampsia diantaranya Nisa et $\mathrm{al}^{16}(\mathrm{p}=0,001), \operatorname{Bardja}^{17}(\mathrm{p}=0,000)$, Andriyani $^{30}(p=0,001)$, Luealon dan Phupong $^{31}(\mathrm{p}=0,009)$, Verma et $\mathrm{al}^{34}(\mathrm{p}=0,001)$, dan Harutyunyan et $\mathrm{al}^{39}(\mathrm{p}=0,0005)$. Dari keenam literatur tersebut diperoleh nilai $\mathrm{p}<0,05$ yang berarti terdapat hubungan antara riwayat preeklampsia dengan kejadian preeklampsia.

Berdasarkan penelitian Bhattacharya et al, ${ }^{53}$ wanita dengan riwayat preeklampsia pada kehamilan sebelumnya berisiko 5,12 kali untuk mengalami preeklampsia dibandingkan wanita dengan normotensi pada kehamilan sebelumnya. Penelitian dari Benschop et al ${ }^{54}$ menyebutkan bahwa $41,5 \%$ dari total 200 wanita dengan preeklampsia sebelumnya mengalami hipertensi satu tahun setelah melahirkan.

Preeklampsia sebelumnya merupakan faktor risiko terjadinya preeklampsia, mungkin karena ketidakmampuan sistem kardiovaskular untuk pulih dari preeklampsia karena profil kardiovaskular pada wanita dengan preeklampsia berulang lebih buruk dibandingkan dengan mereka yang memiliki kehamilan normal sesudahnya. Wanita dengan preeklampsia berulang mengalami peningkatan ketebalan karotis intima-media, serta curah jantung yang lebih rendah (CO) dan massa ventrikel kiri, dibandingkan dengan wanita dengan kehamilan lanjutan normal. ${ }^{55}$

\section{Kehamilan ganda}

Didapatkan lima literatur yang meneliti hubungan antara kehamilan ganda dengan kejadian preeklampsia diantaranya Bardja ${ }^{17}$ $(\mathrm{p}=0,061)$, Luealon dan Phupong ${ }^{31}(\mathrm{p}=$ $0,02)$, Laine et $\mathrm{al}^{31}(p=0,001)$, Shao et $\mathrm{al}^{36}$ $(\mathrm{p}=0,0001)$, dan Das et $\mathrm{al}^{38}(p=0,000)$. Dari literatur tersebut didapatkan empat peneliti- 
an yang memperoleh nilai $\mathrm{p}<0,05$ yang berarti terdapat hubungan antara kehamilan ganda dengan terjadinya preeklampsia.

Pada kehamilan kembar, kadar sFlt1 yang bersirkulasi dan rasio sFlt1/ PIGF dua kali lebih tinggi dibandingkan pada kehamilan tunggal. Kadar sFlt1 serum yang meningkat pada kehamilan kembar tidak disertai dengan perubahan kadar sFlt1 mRNA dan protein HIF-1alpha di plasenta kembar tetapi berkorelasi dengan peningkatan berat plasenta. Temuan ini menunjukkan bahwa peningkatan risiko preeklampsia pada kehamilan kembar mungkin disebabkan oleh peningkatan massa plasenta yang menyebabkan peningkatan kadar sFlt1 dalam sirkulasi. ${ }^{56}$

\section{Riwayat preeklampsia keluarga}

Literatur yang meneliti faktor risiko riwayat preeklampsia keluarga diantaranya Nisa et $\mathrm{al}^{16}(\mathrm{p}=0,001), \operatorname{Bardja}^{17}(\mathrm{p}=0,001)$, dan Verma et $\mathrm{al}^{34}(\mathrm{p}=0,001)$. Berdasarkan tiga literatur tersebut, didapatkan nilai $\mathrm{p}<0,05$ yang berarti terdapat hubungan antara riwayat preeklampsia keluarga dengan kejadian preeklampsia.

Riwayat preeklampsia keluarga dari ibu dengan onset awal, menengah, atau akhir masing-masing 2,15 kali, 2,08 kali, dan 1,49 berisiko dibandingkan dengan wanita tanpa riwayat preeklampsia dalam keluarganya. Riwayat preeklampsia keluarga dari ayah tidak terlalu berpengaruh. Hubungan preeklampsia dengan riwayat preeklampsia keluarga dari ibu memiliki pengaruh yang sama dengan wanita nuliparitas. ${ }^{57}$ Meskipun sebagian besar kasus preeklampsia terjadi pada wanita tanpa riwayat keluarga, kehadiran preeklampsia pada kerabat tingkat pertama meningkatkan risiko wanita untuk mengalami preeklampsia berat sebesar dua hingga empat kali lipat. ${ }^{58}$

\section{Jarak antar kehamilan}

Dari 30 literatur yang dikumpulkan, didapatkan empat literatur yang meneliti hubungan jarak antar kehamilan dengan kejadian preeklampsia, yaitu Fajarsari dan Prabandari $^{18} \quad(p=0,000)$, Wulandari ${ }^{19} \quad(p=$ $0,006)$, Verma et $\mathrm{al}^{34}(\mathrm{p}=0,476)$, dan Harut- yunyan et $\mathrm{al}^{39}(\mathrm{p}=0,0005)$. Tiga literatur yang dilakukan kajian memperoleh nilai $\mathrm{p}<$ 0,05 yang berarti terdapat hubungan antara jarak antar kehamilan dengan kejadian preeklampsia.

Risiko terjadinya preeklampsia meningkat seiring peningkatan usia ibu. Hubungan ini dapat berkontribusi pada peningkatan jarak antar kehamilan. Berdasarkan penelitian Skjaerven, risiko preeklampsia terkait peningkatan jarak antar kehamilan tetap ada meski usia ibu hamil telah dikontrol. Ditemukan juga bahwa wanita dengan multiparitas yang hamil 10 tahun atau lebih dari kehamilan sebelumnya dapat mengalami preeklampsia seperti halnya wanita nuliparitas. ${ }^{59}$

\section{Tingkat sosioekonomi}

Untuk mengetahui hubungan sosial ekonomi dengan kejadian preeklampsia maka digunakan literatur yang membahas karakteristik tingkat pendidikan dan pekerjaan dari ibu hamil. Literatur yang membahas karakteristik tingkat pendidikan didapatkan lima penelitian yaitu, Sadidi et al ${ }^{14}$ $(p=0,039)$, Bardja $^{17}(p=0,000)$, Opitasari danAndayasari $^{24}(\mathrm{p}=0,005)$, Andriyani ${ }^{30}(\mathrm{p}=$ $0,001)$, dan Shao et $\mathrm{al}^{36}(\mathrm{p}=0,0001)$. Dari kelima literatur tersebut didapatkan nilai $\mathrm{p}<$ 0,05 yang berarti terdapat hubungan antara tingkat pendidikan dengan kejadian preeklampsia. Pada karakteristik pekerjaan didapatkan empat penelitian yaitu, Bardja ${ }^{17}$ $(\mathrm{p}=0,469)$, Opitasari dan Andayasari ${ }^{24}$ $(\mathrm{p}=0,018)$, Andriyani ${ }^{30}(\mathrm{p}=0,001)$, dan Shao et $\mathrm{al}^{36}(\mathrm{p}=0,0012)$. Dari keempat literatur tersebut, didapatkan tiga literatur yang memperoleh nilai $\mathrm{p}<0,05$ yang berarti terdapat hubungan antara pekerjaan dengan kejadian preeklampsia.

Penelitian oleh Silva et al, menyimpulkan bahwa faktor risiko kuat terjadinya preeklampsia yaitu status sosioekonomi ibu yang rendah. Hasil penelitian ini menunjukkan wanita dengan tingkat pendidikan yang rendah lebih mungkin mengalami preeklampsia 5,12 kali labih tinggi dibandingkan wanita dengan pendidikan yang lebih tinggi. ${ }^{60}$ Menurut Youssef et al, ${ }^{61}$ terdapat hubungan kuat antara tingkat 
pendidikan dan status ekonomi dengan kejadian preeklampsia. ${ }^{61}$ Wanita dengan sosioekonomi rendah cenderung menerima perawatan prenatal lebih jarang dan berisiko lebih tinggi untuk komplikasi kebidanan. Selain itu, wanita dengan sosioekonomi rendah cenderung dirugikan dalam hal pemanfaatan layanan medis. ${ }^{62}$

Wanita hamil dengan sosioekonomi rendah telah terbukti memiliki hasil kebidanan yang kurang baik terkait dengan kunjungan prenatal yang tidak memadai. ${ }^{62}$ Wanita dengan tingkat pendidikan lebih tinggi memiliki kemampuan untuk memperoleh, mengolah, dan memahami informasi kesehatan. Dapat bertanya dan berdiskusi dengan petugas kesehatan serta dapat mengambil keputusan sendiri. ${ }^{63}$

\section{Penyakit autoimun}

Pada faktor risiko autoimun hanya ditemukan satu literatur yang meneliti hubungan autoimun dengan kejadian preeklampsia yaitu Rajaei et $\mathrm{al}^{40}$ yang mendapatkan nilai $\mathrm{p}=0,003$ yang berarti terdapat hubungan antara autoimun dengan preeklampsia.

Kehamilan dengan SLE memiliki risiko yang tinggi untuk mengalami preeklampsia. Pada 5-8\% kehamilan di Amerika Serikat menyebabkan komplikasi berupa preeklampsia. Angka preeklampsia berkisar antara $13 \%$ sampai $35 \%$ dalam kelompok kehamilan dengan lupus. Preeklampsia diduga muncul dari disfungsi vaskular di plasenta. Beberapa penanda eksperimental untuk preeklampsia, termasuk sFlt-1 dan PIGF, telah ditemukan berhubungan dengan preeklampsia pada pasien lupus seperti yang terdapat pada wanita dengan SLE. Wanita dengan risiko khusus untuk preeklampsia berada pada kehamilan pertama mereka, memiliki komplemen rendah, obesitas, memiliki SLE aktif saat konsepsi, memiliki antibodi anti-dsDNA atau RNP positif, memiliki riwayat preeklampsia atau penyakit ginjal, dan/atau hipertensi. ${ }^{64}$

Dari data kohort 13.555 wanita hamil dengan SLE, sebanyak 22,5\% mengalami komplikasi preeklampsia. ${ }^{42}$ Dari penelitian yang dilakukan Miyamoto et al, ${ }^{65}$ dari 17 pasien yang dilaporkan mengalami SLE, komplikasi yang paling banyak dialami yaitu preeklampsia.

\section{SIMPULAN}

Faktor risiko yang berhubungan dengan terjadinya preeklampsia antara lain usia ibu hamil berisiko, nuliparitas, primigravida, obesitas, riwayat diabetes melitus, riwayat hipertensi kronik, riwayat penyakit ginjal, riwayat preeklampsia, riwayat preeklampsia keluarga, jarak antar kehamilan, tingkat sosioekonomi yang rendah, dan penyakit autoimun. Setelah melakukan penelitian ini, faktor risiko yang paling banyak dibahas yaitu usia ibu hamil.

\section{Konflik Kepentingan}

Penulis menyatakan tidak terdapat konflik kepentingan dalam studi ini.

\section{DAFTAR PUSTAKA}

1. Shetty AK. Global Maternal, Newborn, and Child Health: Successes, Challenges, and Opportunities. Pediatr Clin North Am [Internet]. 2016;63(1):1-18.

2. Davis NL, Smoots AN, Goodman DA. Pregnancy-Related Deaths: Data from 14 U. S. Maternal Mortality Review Committees. MMRIA. 2017;13:3-6.

3. Penelitian dan Pengembangan Kesehatan Kementerian Kesehatan RI. Laporan Nasional Riskesdas 2018. Kementeri Kesehat Republik Indones [Internet]. 2018; Available from: http://www. yankes.kemkes.go.id/assets/downloads/ PMK No. 57 Tahun 2013 tentang PTRM.pdf

4. Kementerian Kesehatan Republik Indonesia. Infodatin Data and Information Center Ministry of Health Republic of Indonesia (Mother's day). Pusat Data dan Informasi Kementerian Kesehatan RI. 2014. p. 1-6.

5. Indonesia KKR. Profil Kesehatan Indonesia Tahun 2019. Kementeri Kesehatan Republik Indones. 2019;

6. Shah S, Gupta A. Hypertensive disorders of pregnancy. Cardiol Clin. 2019;37(3): 345-54.

7. Wilkerson RG, Ogunbodede AC. Hypertensive disorders of pregnancy. Emerg Med 
Clin North Am. 2019;37(2):301-16.

8. Deak TM, Moskovitz JB. Hypertension and pregnancy. Emerg Med Clin North Am. 2012;30(4):903-17.

9. Martadiansyah A, Qalbi A, Santoso B. Prevalensi kejadian preeklampsia dengan komplikasi dan faktor risiko yang mempengaruhinya di RSUP Dr. Mohammad Hoesin Palembang (Studi Prevalensi Tahun 2015, 2016, 2017). Sriwij J Med. 2019;2(1):231-41.

10. Perdana RA, Surya I, Sanjaya IH. Obesitas dan resistensi insulin merupakan faktor risiko terjadinya preeklampsia. Medicina (B Aires). 2019;50(3):493-7.

11. Harumi AM, Armadani DK. Hubungan primigravida dengan kejadian preeklampsia pada ibu hamil di Puskesmas Jagir Surabaya. Midwifery J (J Kebidanan UM Mataram). 2019;4(2): 79.

12. Aulia D, Rodiani, Graharti R. Hubungan diabetes melitus dengan kejadian preeklampsia di RSUD DR. H. Abdul Moeloek Provinsi Lampung Periode 1 Januri-30 Juni 2018. J Medula. 2019; 8:180-6.

13. Rahmawati I, Anies, Adi MS, Hadi C. Maternal age $\geq 35$ years, nulliparity, high blood $\mathrm{COHb}$ levels, and low serum nitric oxide levels increased risk of preeclampsia. Indian $\mathbf{J}$ Forensic Med Toxicol. 2020;14(3):311-7.

14. Sadidi M, Bustan MN, Gobel FA, Sartika. Analisis Faktor Risiko kejadian preeklampsia di RSKD Ibu dan Anak Siti Fatimah Kota Makassar. J Heal Care Media. 2019;3(5):19-24.

15. Mukhoirotin, Fatmawati DA, Shofiana N. Relationship between age and gravidity with pre-eclampsia incident among pregnant women at Puskesmas Cukir Jombang. 2nd Jt Int Conf [Internet]. 2018;2(2):367-72.

16. Nisa R, Kartasurya MI, Fatimah S. Asupan vitamin D, obesitas dan paparan asap rokok sebagai faktor risiko preeklampsia. Manaj Kesehat Indones. 2018;6:204-9.

17. Bardja S. Faktor risiko kejadian preeklampsia berat/eklampsia pada ibu hamil. Embrio J Kebidanan. 2020;12:18-30.

18. Fajarsari D, Prabandari F. Pengaruh umur dan interval persalinan terhadap kejadian preeklamsi di Kabupaten Banyumas. J Publ Kebidanan. 2018;9(2):121-30.
19. Wulandari S. Hubungan antara jarak kehamilan dan status gizi dengan kejadian preeklamsi pada ibu hamil di RS Aura Syifa Kabupaten Kediri Tahun 2015. J Kebidanan Midwiferia. 2016;2.

20. Laila EF. Usia, paritas, riwayat hipertensi dan frekuensi pemeriksaan anc terhadap kejadian preeklampsiapada ibu hamil. J Kebidanan Malahayati. 2019;5(2):12836.

21. Haryani AP, Maroef M, Adilla SN. Hubungan usia ibu hamil berisiko dengan kejadian preeklampsia/eklampsia di RSU Haji Surabaya Periode 1 Januari 2013 - 31 Desember 2013. Saintika Med. 2015; 11(1):27-33.

22. Arwan B, Sriyanti R. Relationship between gravida status, age , BMI (Body Mass Index) and preeclampsia. Andalas Obstet Gynecol J. 2020;4(1):13-21.

23. Hasliani A. Hubungan riwayat hipertensi dengan kejadian preeklampsia di RSUD Pangkep. J Ilm Kesehat Diagnosis. 2018;12(1):93-8.

24. Opitasari C, Andayasari L. Parity, education level and risk for (pre-) eclampsia in selected hospitals in Jakarta. Heal Sci J Indones. 2014;5(1):35-9.

25. Kurniasari D, Arifandini F. Hubungan usia, paritas dan diabetes mellitus pada kehamilan dengan kejadian preeklamsia pada ibu hamil di wilayah kerja Puskesmas Rumbia Kabupaten. J Kesehat Holistik. 2015;9(3):142-50.

26. Marniarti, Rahmi N, Djokosujono K. Analisis hubungan usia, status gravida dan usia kehamilan dengan pre- eklampsia pada ibu hamil di Rumah Sakit Umum dr . Zaionel Abidin Provinsi Aceh Tahun (Relationship analysis of age, gravida status and age of pregnancy with preeclampsia in pregnant women. J Healthc Technol Med. 2016;2(1):99109.

27. Wahyuni R, Azhari, Syukur NA. Hubungan obesitas dengan preeklampsia pada ibu hamil trimester II dan III. Mahakam Midwifery J. 2019;2(5):312.

28. Denantika O, Serudji J, Revilla G. Hubungan status gravida dan usia ibu terhadap kejadian preeklampsia di RSUP Dr. M. Djamil Padang Tahun 2012-2013. J Kesehat Andalas. 2015;4(1):212-7.

29. Yanuarini TA, Suwoyo, Julianawati T. Hubungan status gravida dengan kejadi- 
an preeklampsia (The correlation between gravida status with the incidence of preeklampsia). J kebidanan. 2020;9(1).

30. Andriyani R. Faktor risiko kejadian preeklampsia di RSUD Arifin Achmad. J Kesehat Komunitas. 2012;2(1):26-30.

31. Luealon P, Phupong V. Risk factors of preeclampsia in thai women. $\mathrm{J}$ Med Assoc Thail. 2010;93(6):661-6.

32. Tangren JS, Adnan WM, Hafiz WA, Powe CE, Ecker J, Bramham K, et al. Risk of preeclampsia and pregnancy complications in women with a history of acute kidney injury. Hypertension. 2018; 72(2):451-9.

33. Laine K, Murzakanova G, Sole KB, Pay AD, Heradstveit S, Raiisänen S. Prevalence and risk of pre-eclampsia and gestational hypertension in twin pregnancies: a population-based register study. BMJ Open. 2019;9(7):1-8.

34. Verma MK, Kapoor P, Yadav R, Manohar RK. Risk Factor assessment for preeclampsia: a case control study. Int J Med Public Heal. 2017;7(3):172-7.

35. Quan LM, Xu QL, Zhang GQ, Wu LL, Xu H. An analysis of the risk factors of preeclampsia and prediction based on combined biochemical indexes. Kaohsiung J Med Sci. 2018;34(2):10912.

36. Shao Y, Qiu J, Huang H, Mao B, Dai W, He $\mathrm{X}$, et al. Pre-pregnancy BMI, gestational weight gain and risk of preeclampsia: A birth cohort study in Lanzhou, China. BMC Pregnancy Childbirth. 2017; 17(1):2-9.

37. Hussein YA, Ali RK, Alezzi JI. Preeclampsia: Maternal risk factors \& perinatal outcomes. Pediatr Pract Res. 2018;6(2): 10-5.

38. Das S, Das R, Bajracharya R, Baral G, Jabegu $\mathrm{B}$, Odland $\mathrm{J} \emptyset$, et al. Incidence and risk factors of pre-eclampsia in the paropakar maternity and women's hospital, Nepal: A retrospective study. Int J Environ Res Public Health. 2019;16(19):1-8.

39. Harutyunyan A, Armenian H, Petrosyan V. Interbirth interval and history of previous preeclampsia: a case-control study among multiparous women. BMC Pregnancy Childbirth. 2013;13:244.

40. Rajaei E, Shahbazian N, Rezaeeyan H,
Mohammadi AK, Hesam S, Zayeri ZD. The effect of lupus disease on the pregnant women and embryos: a retrospective study from 2010 to 2014 . Clin Rheumatol. 2019;38(11):3211-5.

41. Kementerian Kesehatan Republik Indonesia. Situasi Kesehatan Reproduksi Remaja [Internet]. INFODATIN Pusat Data dan Informasi Kementerian Kesehatan RI. 2014. p. 1. Available from: https://www. kemkes.go.id/download.php?file=down load/pusdatin/infodatin/infodatin reproduksi remaja-ed.pdf

42. Cunningham FG, Leveno KJ, Bloom SL, Spong CY, Dashe JS, Hoffman BL, et al. Williams Obstetrics (24th ed). New York: McGraw-Hill Education, 2014.

43. Lamminpää R, Vehviläinen-Julkunen $\mathrm{K}$, Gissler M, Heinonen S. Preeclampsia complicated by advanced maternal age: a registry-based study on primiparous women in Finland 1997-2008. BMC Pregnancy Childbirth. 2012;12(1):47.

44. Bdolah Y, Elchalal U, Natanson-Yaron S, Yechiam H, Bdolah-Abram T, Greenfield $\mathrm{C}$, et al. Relationship between nulliparity and preeclampsia may be explained by altered circulating soluble fms-like tyrosine kinase 1. Hypertens pregnancy. 2014 May;33(2):250-9.

45. Roberts JM, Bodnar LM, Patrick TE, Powers RW. The role of obesity in preeclampsia. Pregnancy Hypertens. 2011; 1(1):6-16.

46. Sibai BM, Gordon T, Thom E, Caritis SN, Klebanoff M, McNellis D, et al. Risk factors for preeclampsia in healthy nulliparous women: a prospective multicenter study. The National Institute of Child Health and Human Development Network of Maternal-Fetal Medicine Units. Am J Obstet Gynecol. $1995 \mathrm{Feb} ; 172(2 \mathrm{Pt}$ 1):642-8.

47. Lopez-Jaramillo P, Barajas J, Rueda-Quijano SM, Lopez-Lopez C, Felix C. Obesity and preeclampsia: common pathophysiological mechanisms. Front Physiol. 2018;9:1-10.

48. Yanit KE, Snowden JM, Cheng YW, Caughey $\mathrm{AB}$. The impact of chronic hypertension and pregestational diabetes on pregnancy outcomes. Am J Obstet Gynecol. 2012;207(4):333e1-6.

49. Uddin MN, Beeram MR, Kuehl TJ. Diabetes mellitus and preeclampsia. Med J Obstet 
Gynecol. 2013;1(3):1016.

50. Seely EW, Ecker J. Chronic hypertension in pregnancy. Circulation. 2014;129(11): 1254-61.

51. Kartika AR, Aldika Akbar MI, Umiastuti P. Risk factor of severe preeclampsia in Dr. Soetomo Hospital Surabaya in 2015. Maj Obstet Ginekol. 2018;25(1):6.

52. Reis IP, Vais A, Piercy CN, Anita B. Renal disease and hypertension in pregnancy. Clin Med (Northfield Il). 2013;13(1):62.

53. Bhattacharya S, Campbell DM, Smith NC. Preeclampsia in the Second Pregnancy: Does Previous Outcome Matter? Obstet Gynecol Surv. 2009;64(9). Available from:

https://journals.lww.com/obgynsurvey/ Fulltext/2009/09000/Preeclampsia_in_t he_Second_Pregnancy_Does.7.aspx

54. Benschop L, Duvekot JJ, Versmissen J, Van Broekhoven V, Steegers EAP, Roeters Van Lennep JE. Blood pressure profile 1 year after severe preeclampsia. Hypertension. 2018;71(3):491-8.

55. Thilaganathan B, Kalafat E. Cardiovascular system in preeclampsia and beyond. Hypertension. 2019;73(3):522-31.

56. Bdolah Y, Lam C, Rajakumar A, Shivalingappa V, Mutter W, Sachs BP, et al. Twin pregnancy and the risk of preeclampsia: bigger placenta or relative ischemia? Am J Obstet Gynecol. 2008;198(4):428.e1-428.e6.

57. Boyd HA, Tahir H, Wohlfahrt J, Melbye M. Associations of personal and family preeclampsia historywith the risk of early-, intermediate- and late-onset preeclampsia. Am J Epidemiol. 2013; 178(11):1611-9.
58. Wang A, Rana S, Karumanchi SA. Preeclampsia: The role of angiogenic factors in its pathogenesis. Physiology. 2009;24(3):147-58.

59. Skjaerven R, Wilcox AJ, Lie RT. The Interval between pregnancies and the risk of preeclampsia. New Engl J Med. 2003; 346(1):34-6.

60. Silva LM, Coolman M, Steegers EA, Jaddoe VW, Moll HA, Hofman A, et al. Low socioeconomic status is a risk factor for preeclampsia: the Generation R Study. J Hypertens. 2008;26(6):1200-8.

61. Youssef AE-DA, Mohamed MH, Habib DME-S, Moussa SSA. Effect of Socioeconomic Status on Preeclampsia Cross Sectional Study. Med J Cairo Univ. 2018;86(12):4227-34.

62. Kim MK, Lee SM, Bae SH, Kim HJ, Lim NG, Yoon SJ, et al. Socioeconomic status can affect pregnancy outcomes and complications, even with a universal healthcare system. Int J Equity Health. 2018;17(1):2.

63. Buehler JW, Kaunitz AM, Hogue CJR, Hughes JM, Smith JC, Rochat RW. Maternal Mortality in Women Aged 35 Years or Older: United States. JAMA J Am Med Assoc. 1986;255(1):53-7.

64. Clowse MEB. Lupus Activity in Pregnancy. Rheum Dis Clin North Am. 2007; 33(2):237-52.

65. Miyamoto T, Hoshino T, Hayashi N, Oyama $\mathrm{R}$, Okunomiya A, Kitamura $\mathrm{S}$, et al. Preeclampsia as a Manifestation of New-Onset Systemic Lupus Erythematosus during Pregnancy: A Case-Based Literature Review. Am J Perinatol Reports. 2015;06(01):e62-7. 